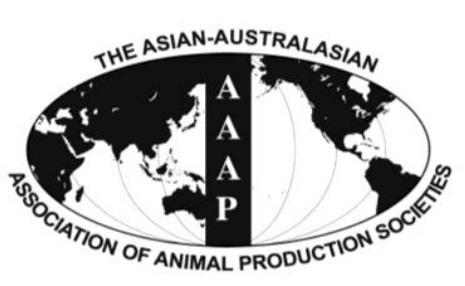

Open Access

Asian Australas. J. Anim. Sci.

Vol. 28, No. 3 : 343-350 March 2015

http://dx.doi.org/10.5713/ajas.13.0798

www.ajas.info

pISSN 1011-2367 elSSN 1976-5517

\title{
Improving Nutritional Quality of Cocoa Pod (Theobroma cacao) through Chemical and Biological Treatments for Ruminant Feeding: In vitro and In vivo Evaluation
}

\author{
Erika B. Laconi and Anuraga Jayanegara* \\ Department of Animal Nutrition and Feed Technology, Faculty of Animal Science, \\ Bogor Agricultural University, Bogor 16680, Indonesia
}

\begin{abstract}
Cocoa pod is among the by-products of cocoa (Theobroma cacao) plantations. The aim of this study was to apply a number of treatments in order to improve nutritional quality of cocoa pod for feeding of ruminants. Cocoa pod was subjected to different treatments, i.e. C (cocoa pod without any treatment or control), CAm (cocoa pod $+1.5 \%$ urea), CMo (cocoa pod $+3 \%$ molasses), CRu (cocoa pod $+3 \%$ rumen content) and $\mathrm{CPh}$ (cocoa pod $+3 \%$ molasses + Phanerochaete chrysosporium inoculum). Analysis of proximate and Van Soest's fiber fraction were performed on the respective treatments. The pods were then subjected to an in vitro digestibility evaluation by incubation in rumen fluid-buffer medium, employing a randomized complete block design ( $\mathrm{n}=3$ replicates). Further, an in vivo evaluation of the pods ( $35 \%$ inclusion level in total mixed ration) was conducted by feeding to young Holstein steers (average body weight of $145 \pm 3.6 \mathrm{~kg}$ ) with a $5 \times 5$ latin square design arrangement $(\mathrm{n}=5$ replicates). Each experimental period lasted for $30 \mathrm{~d}$; the first $20 \mathrm{~d}$ was for feed adaptation, the next $3 \mathrm{~d}$ was for sampling of rumen liquid, and the last $7 \mathrm{~d}$ was for measurements of digestibility and $\mathrm{N}$ balance. Results revealed that lignin content was reduced significantly when cocoa pod was treated with urea, molasses, rumen content or $P$. chrysosporium $(\mathrm{p}<0.01$ ) with the following order of effectiveness: $\mathrm{CPh}>\mathrm{CAm}>\mathrm{CRu}>\mathrm{CMo}$. Among all treatments, $\mathrm{CAm}$ and $\mathrm{CPh}$ treatments significantly improved the in vitro dry matter and organic matter digestibility $(\mathrm{p}<0.05)$ of cocoa pod. Average daily gain of steers receiving $\mathrm{CAm}$ or $\mathrm{CPh}$ treatment was significantly higher than that of control $(\mathrm{p}<0.01)$ with an increase of $105 \%$ and $92 \%$, respectively. Such higher daily gain was concomitant with higher $\mathrm{N}$ retention and proportion of $\mathrm{N}$ retention to $\mathrm{N}$ intake in $\mathrm{CAm}$ and $\mathrm{CPh}$ treatments than those of control $(\mathrm{p}<0.05)$. It can be concluded from this study that treatment with either urea or P. chrysosporium is effective in improving the nutritive value of cocoa pod. (Key Words: Cocoa Pod, Digestibility, Rumen, Steer, Treatment)
\end{abstract}

\section{INTRODUCTION}

Livestock production depends on the availability and quality of feed provided to the animal. For ruminant animals, forages such as grasses and legumes are the main source of feeds to satisfy their nutritional requirements, either for maintenance, production or reproduction. However, sufficient forage may not be available throughout the year due to low production during the dry season and thus providing an alternative feed resource is important in order to maintain animals. To avoid competition, ideally the

\footnotetext{
* Corresponding Author: Anuraga Jayanegara. Tel: +62-251-8626 213, Fax: +62-251-8626213, E-mail: anu_jayanegara@yahoo.com Submitted Dec. 6, 2013; Revised Feb. 25, 2014; Accepted Oct. 9, 2014
}

alternative feed resource should not be utilized for human consumption. Accordingly, a number of agricultural byproducts have the potential as alternative feeds due to their abundant quantity as well as their availability throughout the year. Unfortunately, agricultural by-products are usually characterized by their low nutritional quality; they contain highly fibrous materials and low protein content. Such characteristics often lead the by-products to be treated, either physically, chemically and/or biologically prior to feeding to animals (Sarnklong et al., 2010; Kim et al., 2012).

Cocoa (Theobroma cacao) is primarily grown for its bean to be further processed by the chocolate industry. The bean itself is located inside the cocoa fruit. When the bean is removed from its fruit, the leftover is called the pod and may constitute about $75 \%$ of the weight of the whole fruit

Copyright @ 2015 by Asian-Australasian Journal of Animal Sciences This is an open-access article distributed under the terms of the Creative Commons Attribution Non-Commercial License (http://creativecommons.org/licenses/by-nc/3.0/), which permits unrestricted non-commercial use, distribution, and reproduction in any medium, provided the original work is properly cited. 
(Owusu-Domfeh, 1972). Although other by-products from cocoa processing such as cocoa shell and cocoa dust exist and may also be used as animal feeds (Aregheore, 2002), the pod is the predominant cocoa by-product.

Indonesia is the second largest producer of cocoa in terms of total production after the Ivory Coast (FAOSTAT, 2013). Therefore, quite an amount of cocoa by-product is available in the country, especially in the areas of cocoa plantations or where cocoa processing plants are located. Unfortunately, despite its abundant quantity, so far cocoa pod has not been optimally utilized by farmers. Usually the pod is left to rot on the plantation area or is used as mulching material. If the cocoa pod could be fed to animals, its economic value would be improved.

A main obstacle of utilizing cocoa pod as an animal feed is its high fiber and low protein contents (Sutikno, 1997). Further, it contains a considerable amount of lignin, i.e. between $12 \%$ to $19 \%$ dry matter (DM), and such value is 2 to 3 times higher than that of rice straw (Sutikno, 1997). Studies using high inclusion levels of untreated cocoa pod in diets have resulted in lower digestibility and animal performance (Devendra, 1977; Smith and Adegbola, 1985), confirming its low nutritional quality. Two main nutritional strategies have been proposed to overcome such limitation of cocoa pod, i.e. either by mixing with a more fermentable or digestible feedstuff (Aregheore, 2002) or by treating the pod with certain chemical or biological agents to improve its digestibility (Alemawor et al., 2009; Zain, 2009). However, to date, there is still a lack of studies that attempt to compare and to determine which treatment is most appropriate to improve the nutritional quality of cocoa pod in the context of animal nutrition.

The aim of the present study was therefore to compare a number of treatments in order to improve nutritional quality of cocoa pod. Accordingly, ammoniation technique (urea treatment), fermentation with addition of molasses or rumen content, and inoculation with a white rot fungi species (Phanerochaete chrysosporium) were compared for their effectiveness to achieve the objective. Chemical composition and in vitro digestibility of cocoa pod were used as indicators of nutritional quality. Further, an in vivo evaluation was performed on young steers fed the treated cocoa pods, in which animal performance and rumen fermentation were observed.

\section{MATERIALS AND METHODS}

\section{Experimental materials and treatments}

All procedures used in the present study had been approved by the Faculty of Animal Science, Bogor Agricultural University, Indonesia. Cocoa pod was obtained from PTP XII Rajamandala, Bandung Regency, West Java, Indonesia. Fresh cocoa pod was chopped manually as homogenous as possible (around $1 \mathrm{~cm}$ thickness) and subjected to the following chemical and biological treatments:

$\mathrm{C}:$ Cocoa pod without any treatment (control)

CAm : Cocoa pod $+1.5 \%$ urea $(w / w)$

CMo : Cocoa pod $+3 \%$ molasses $(w / w)$

$\mathrm{CRu}$ : Cocoa pod $+3 \%$ rumen content $(\mathrm{w} / \mathrm{w})$

$\mathrm{CPh}$ : Cocoa pod $+3 \%$ molasses $(\mathrm{w} / \mathrm{w})+$ Phanerochaete chrysosporium inoculum

Urea and molasses were purchased from a commercial supplier. Rumen content was collected from a fistulated dairy cow housed at the Faculty of Animal Science, Bogor Agricultural University. Phanerochaete chrysosporium inoculum was obtained from the Biotechnology Research Center, Indonesian Academy of Science, Cibinong. For each treatment, $300 \mathrm{~g}$ of chopped cocoa pod was used and with the exception of $\mathrm{CPh}$ were placed in polyethylene bags and kept under anaerobic conditions for $7 \mathrm{~d}$. In the case of $\mathrm{CPh}$, the treated cocoa pod was kept aerobically at room temperature for $7 \mathrm{~d}$. Each treatment was conducted in three replicates $(n=3)$, and each replicate was repeated twice.

The treated cocoa pod was analyzed for proximate composition, i.e. organic matter (OM), crude protein (CP), crude fiber $(\mathrm{CF})$ and ether extract $(\mathrm{EE})$ by following the procedure from AOAC (1995). Nitrogen free extract was obtained by subtracting $\mathrm{CP}, \mathrm{CF}$, and $\mathrm{EE}$ from OM. Determination of fiber fractions, i.e. neutral detergent fiber (NDF), acid detergent fiber (ADF) and lignin was according to Van Soest et al. (1991). Hemicellulose was obtained by difference between NDF and ADF, and similarly, cellulose was obtained by difference between ADF and lignin.

\section{In vitro procedures}

Cocoa pod was incubated in vitro with rumen fluid and McDougall's buffer mixture by following the procedure of Tilley and Terry (1963). Allocation of treatments into in vitro experimental units was following a randomized complete block design. Different batches of rumen fluid were considered as block. A $1 \mathrm{~g}$ sample was weighed and placed into a tube. Subsequently, $12 \mathrm{~mL}$ of McDougall's buffer and $8 \mathrm{~mL}$ of rumen fluid were added. The tube was closed with a rubber cap and incubated anaerobically for 24 $\mathrm{h}$ in an automatic shaker water bath, maintained at $39^{\circ} \mathrm{C}$ during the process. After $24 \mathrm{~h}$, the cap was opened, $0.2 \mathrm{~mL}$ of $\mathrm{HgCl}_{2}$ was added, centrifuged at $10,000 \mathrm{rpm}$ for $10 \mathrm{~min}$, and the supernatant was removed. The residue was combined with $20 \mathrm{~mL}$ of $0.2 \%$ pepsin under acidic condition, and further incubated for $24 \mathrm{~h}$. The remaining sample after the two-stage in vitro incubation procedure was filtered with a Whatman paper no. 41 for determination of in vitro dry matter digestibility (IVDMD) and in vitro organic matter digestibility (IVOMD). Values of IVDMD 
and IVOMD were presented as percentage $(\%)$ of digested substance from their initial amounts prior to incubation. Blanks (rumen fluid and buffer only without sample substrate) were incubated as described above and served as a correction factor to the DM and OM contents of residuals. The incubation was done in three replicates according to the treatments $(n=3)$, and each replicate was represented by two tubes.

\section{In vivo procedures}

Five young Holstein steers (average body weight of $145 \pm 3.6 \mathrm{~kg}$ ) were used as the experimental animals. The steers received five different dietary treatments with a $5 \times 5$ latin square design $(\mathrm{n}=5$ replicates). All diets contained $35 \%$ of cocoa pod (in dry weight), but differed in processing treatments of the pod as described above. Other feedstuffs that made up the rest of the diets consisted of other by-products of cocoa processing, i.e., cocoa bean shell (4\%) and cocoa meal (20\%), palm kernel cake (38\%), premix $(1 \%), \mathrm{CaCO}_{3}(1 \%)$, urea $(0.5 \%)$ and salt $(0.5 \%)$. Total digestible nutrient and $\mathrm{CP}$ content of all diets were designed to be similar, i.e. $65 \%$ and $17 \%$ DM, respectively. Feeds and drinking water were given ad libitum over the experimental period; feeds were provided in equal portions at 8:00 and 16:00 h each day while water was available at all times. All the experimental steers were individually penned to prevent cross feeding of the animals fed different treatments. The experiment was conducted in five periods and each experimental period lasted for $30 \mathrm{~d}$. The first $20 \mathrm{~d}$ was for feed adaptation, the next $3 \mathrm{~d}$ was for sampling of rumen liquid, and the last $7 \mathrm{~d}$ was for measurements of digestibility and $\mathrm{N}$ balance whereas the steers were on metabolism crates to facilitate total collection of urine and faeces.

Parameters measured in this in vivo study were feed intake, digestibility, body weight gain, nitrogen utilization and rumen parameters. With regard to rumen parameters, $\mathrm{pH}$, ammonia $\left(\mathrm{NH}_{3}\right)$ concentration, volatile fatty acid (VFA) profiles, microbial protein production and allantoin urine were observed. Feed intake (as a difference between feed offered and refusal) was recorded daily throughout the experimental period. During the digestibility measurement (the last $7 \mathrm{~d}$ of each period), faeces were collected daily by total collection method and pooled by each steer at the end of each period. An amount of 5\% from total faeces (fresh weight) was sampled for chemical composition determination. Prior to the chemical composition analysis, samples of feeds, feed refusals and faeces were oven-dried at $60^{\circ} \mathrm{C}$ for $48 \mathrm{~h}$ and ground to pass a $1 \mathrm{~mm}$ sieve. Body weight was measured before the morning feeding every 10 $\mathrm{d}$ throughout the experimental period. Nitrogen retention was calculated by subtracting faecal $\mathrm{N}$ and urinary $\mathrm{N}$ from $\mathrm{N}$ intake. Urinary $\mathrm{N}$ was obtained by collecting total urine (on the same days when collecting faeces) with plastic container containing $10 \%$ of sulfuric acid to prevent $\mathrm{N}$ loss. Approximately $10 \%$ of the total urine collected was sampled, kept in a refrigerator, and pooled for each period for $\mathrm{N}$ determination.

Rumen samples were withdrawn from each steer through using a stomach tube at $4 \mathrm{~h}$ post feeding on the $21 \mathrm{st}$ to $23 \mathrm{rd}$ day of each period. Rumen $\mathrm{pH}$ was immediately measured by using a $\mathrm{pH}$ meter. Ammonia concentration was analyzed by the micro-diffusion technique (Conway and Byrne, 1933). Profiles of VFA were analyzed by gas chromatography method using metaphosphoric acid to precipitate protein during sample preparation prior to injection (Cottyn and Boucque, 1968). A VFA standard containing known amounts of acetate $\left(\mathrm{C}_{2}\right)$, propionate $\left(\mathrm{C}_{3}\right)$, butyrate $\left(\mathrm{C}_{4}\right)$, isobutyrate $\left(\right.$ iso $\left.\mathrm{C}_{4}\right)$ and valerate $\left(\mathrm{C}_{5}\right)$ were injected as a basis of VFA quantification in the samples. Total VFA was the sum of individual VFA measured. Microbial protein synthesis in the rumen and allantoine urine were determined according to Bucholtz and Bergen (1973) and Zinn and Owens (1986), respectively.

\section{Statistical analysis}

Statistical model used for the in vitro experiment was as follows: $Y_{i j}=\mu+\tau_{i}+\beta_{j}+\varepsilon_{i j}$, where $Y_{i j}$ is the dependent variable, $\mu$ is the overall mean, $\tau_{\mathrm{i}}$ is the fixed effect of treatment $(\mathrm{i}=1,2,3,4,5), \beta_{\mathrm{j}}$ is the fixed effect of block $(\mathrm{j}=$ $1,2,3)$, and $\varepsilon_{\mathrm{ij}}$ is the random residual error. For the in vivo experiment, the statistical model used was as follows: $\mathrm{Y}_{\mathrm{ijk}}=$ $\mu+\tau_{i}+\beta_{j}+\rho_{k}+\varepsilon_{i j k}$, where $Y_{i j k}$ is the dependent variable, $\mu$ is the overall mean, $\tau_{\mathrm{i}}$ is the fixed effect of treatment $(\mathrm{i}=1,2$, $3,4,5), \beta_{\mathrm{j}}$ is the fixed effect of animal or steer $(\mathrm{j}=1,2,3,4$, $5), \rho_{\mathrm{k}}$ is the fixed effect of period $(\mathrm{k}=1,2,3,4,5)$, and $\varepsilon_{\mathrm{ijk}}$ is the random residual error. Data obtained were subjected to analysis of variance according to the corresponding statistical models above, tested at $\mathrm{p}<0.05$ and $\mathrm{p}<0.01$. When a parameter showed significantly different at $\mathrm{p}<0.05$ or $\mathrm{p}<0.01$, the means among various treatments were further tested with a post-hoc test, i.e. Duncan's test. Relationship between various parameters was assessed by using principal component analysis (PCA) as previously conducted by Jayanegara et al. (2011).

\section{RESULTS}

\section{Chemical composition and in vitro evaluation}

Treatment of $\mathrm{CPh}$ increased $\mathrm{CP}$ content of the pod compared to that of control $(\mathrm{p}<0.05)$, while other treatments did not (Table 1). All treatments resulted in a significant $(\mathrm{p}<0.01)$ decrease in $\mathrm{CF}$ content compared to the untreated cocoa pod. With regard to Van Soest's fiber fractions (Table 2), almost all treatments, with the exception of CAm resulted in a significant decrease $(\mathrm{p}<0.01)$ in NDF content. 
Table 1. Influence of various chemical and biological treatments on proximate composition of cocoa pod

\begin{tabular}{lcccccc}
\hline \multirow{2}{*}{ Component } & \multicolumn{7}{c}{ Treatment $^{1}$} & \\
\cline { 2 - 6 } & $\mathrm{C}$ & $\mathrm{CAm}$ & $\mathrm{CMo}$ & $\mathrm{CRu}$ & $\mathrm{CPh}$ & p-value \\
\hline $\mathrm{OM}$ & 87.1 & 87.7 & 87.2 & 87.4 & 87.9 & $\mathrm{~ns}$ \\
$\mathrm{CP}$ & $8.4^{\mathrm{a}}$ & $9.6^{\mathrm{ab}}$ & $8.8^{\mathrm{ab}}$ & $8.3^{\mathrm{a}}$ & $10.0^{\mathrm{b}}$ & $<0.05$ \\
$\mathrm{CF}$ & $55.7^{\mathrm{d}}$ & $50.9^{\mathrm{c}}$ & $49.1^{\mathrm{c}}$ & $40.4^{\mathrm{a}}$ & $45.6^{\mathrm{b}}$ & $<0.01$ \\
$\mathrm{EE}$ & $2.5^{\mathrm{c}}$ & $2.2^{\mathrm{c}}$ & $0.4^{\mathrm{a}}$ & $0.2^{\mathrm{a}}$ & $1.6^{\mathrm{b}}$ & $<0.01$ \\
$\mathrm{NFE}$ & $20.6^{\mathrm{a}}$ & $25.0^{\mathrm{b}}$ & $29.0^{\mathrm{c}}$ & $38.4^{\mathrm{d}}$ & $30.6^{\mathrm{c}}$ & $<0.01$ \\
\hline
\end{tabular}

$\mathrm{OM}$, organic matter; $\mathrm{CP}$, crude protein; $\mathrm{CF}$, crude fiber; $\mathrm{EE}$, ether extract; NFE, nitrogen free extract.

${ }^{1} \mathrm{C}$, cocoa pod without any treatment; CAm, ammoniated cocoa pod with $1.5 \%$ urea; $\mathrm{CMo}$, fermented cocoa pod with $3 \%$ molasses; $\mathrm{CRu}$, fermented cocoa pod with $3 \%$ rumen content; $\mathrm{CPh}$, fermented cocoa pod with 3\% molasses and Phanerochaete chrysosporium inoculum.

Various superscripts within the same row are significantly different at least at $\mathrm{p}<0.05$.

Content of ADF decreased by $11.8 \%, 11.1 \%, 6.2 \%$, or $7.4 \%$ $(\mathrm{p}<0.01)$ when cocoa pod was treated by urea, molasses, rumen content or $P$. chrysosporium, respectively. Whilst treatment with either urea or molasses increased the hemicellulose content of cocoa pod compared to the control $(p<0.01)$, it did not affect cellulose content. Lignin content was reduced significantly when cocoa pod was treated with urea, molasses, rumen content or $P$. chrysosporium ( $\mathrm{p}<0.01$ ). The order of effectiveness of a treatment in reducing lignin was as follows: $\mathrm{CPh}>\mathrm{CAm}>\mathrm{CRu}>\mathrm{CMo}$.

The decline in ADF and lignin contents in CAm and $\mathrm{CPh}$ treatments was reflected in the digestibility parameter. Accordingly, among all treatments, $\mathrm{CAm}$ and $\mathrm{CPh}$ treatments improved IVDMD and IVOMD $(\mathrm{p}<0.05)$, whereas $\mathrm{CMo}$ and $\mathrm{CRu}$ treatments did not differ from that
Table 2. Influence of various chemical and biological treatments on Van Soest's fiber fractions of cocoa pod

\begin{tabular}{lcccccc}
\hline \multirow{2}{*}{ Component } & \multicolumn{6}{c}{ Treatment $^{1}$} \\
\cline { 2 - 6 } & $\mathrm{C}$ & $\mathrm{CAm}$ & $\mathrm{CMo}$ & $\mathrm{CRu}$ & $\mathrm{CPh}$ & \\
\hline NDF & $80.7^{\mathrm{c}}$ & $79.0^{\mathrm{c}}$ & $78.4^{\mathrm{b}}$ & $75.1^{\mathrm{a}}$ & $75.0^{\mathrm{a}}$ & $<0.01$ \\
ADF & $74.6^{\mathrm{c}}$ & $65.8^{\mathrm{a}}$ & $66.3^{\mathrm{a}}$ & $70.0^{\mathrm{b}}$ & $69.1^{\mathrm{ab}}$ & $<0.01$ \\
Hemicellulose & $6.0^{\mathrm{a}}$ & $13.2^{\mathrm{b}}$ & $12.2^{\mathrm{b}}$ & $5.0^{\mathrm{a}}$ & $6.0^{\mathrm{a}}$ & $<0.01$ \\
Cellulose & $35.3^{\mathrm{a}}$ & $34.0^{\mathrm{a}}$ & $37.6^{\mathrm{b}}$ & $37.0^{\mathrm{b}}$ & $31.0^{\mathrm{a}}$ & $<0.01$ \\
Lignin & $38.8^{\mathrm{b}}$ & $33.2^{\mathrm{a}}$ & $35.6^{\mathrm{a}}$ & $33.9^{\mathrm{a}}$ & $31.7^{\mathrm{a}}$ & $<0.01$ \\
\hline
\end{tabular}

NDF, neutral detergent fiber; ADF, acid detergent fiber.

${ }^{1} \mathrm{C}$, cocoa pod without any treatment; $\mathrm{CAm}$, ammoniated cocoa pod with $1.5 \%$ urea; $\mathrm{CMo}$, fermented cocoa pod with $3 \%$ molasses; $\mathrm{CRu}$, fermented cocoa pod with $3 \%$ rumen content; $\mathrm{CPh}$, fermented cocoa pod with 3\% molasses and Phanerochaete chrysosporium inoculum.

Various superscripts within the same row are significantly different at $\mathrm{p}<0.01$.

of the control (Figure 1). In comparison to the untreated cocoa pod, urea treatment increased IVDMD and IVOMD of cocoa pod by $42.7 \%$ and $36.1 \%$, respectively, while $P$. chrysosporium treatment increased IVDMD and IVOMD by $27.6 \%$ and $28.5 \%$, respectively.

Loading plot of principal component 1 (PC1) and principal component 2 (PC2) may be used for describing the relationship between parameters. Total variation explained by both PCs was $80.6 \%$, in which PC1 and PC2 contributed for $49.4 \%$ and $31.2 \%$ from the respective value, respectively (Figure 2). Crude protein and OM contents were within the same direction with IVDMD and IVOMD, indicating that these parameters were positively correlated. They were conversely or negatively correlated with cellulose, ADF and lignin contents of cocoa pod. Other parameters appeared to be only slightly related to IVDMD

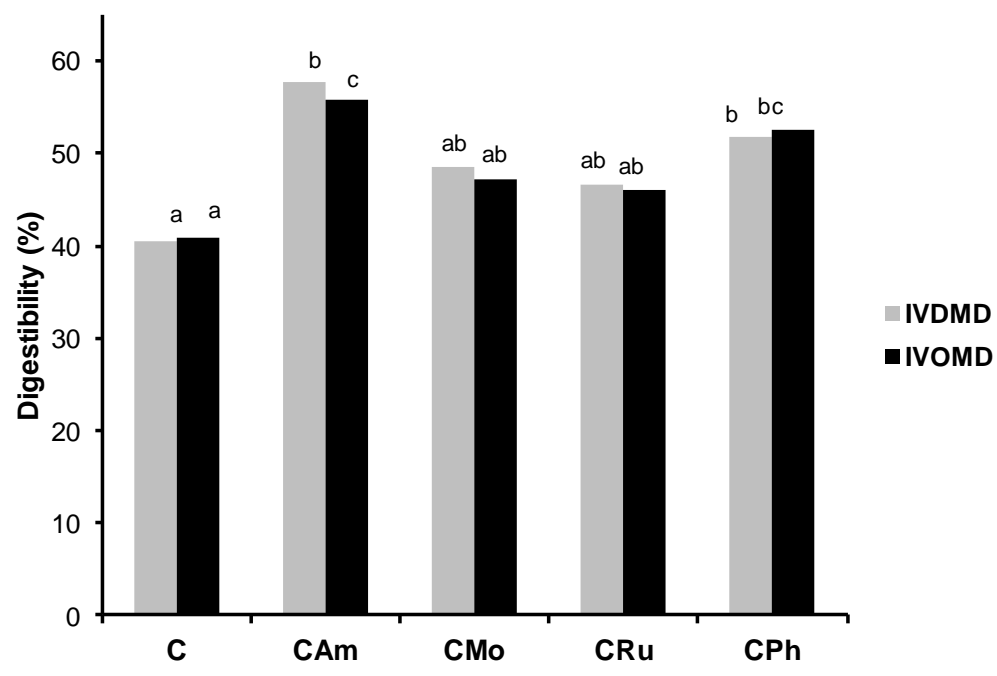

Figure 1. In vitro dry matter digestibility (IVDMD) and in vitro organic matter digestibility (IVOMD) of cocoa pod treated with chemical and biological treatments. Various superscripts above the bars within the same parameter are significantly different at $\mathrm{p}<0.01$. Treatment: C, cocoa pod without any treatment; CAm, ammoniated cocoa pod with $1.5 \%$ urea; CMo, fermented cocoa pod with $3 \%$ molasses; $\mathrm{CRu}$, fermented cocoa pod with $3 \%$ rumen content; $\mathrm{CPh}$, fermented cocoa pod with $3 \%$ molasses and Phanerochaete chrysosporium inoculum. 


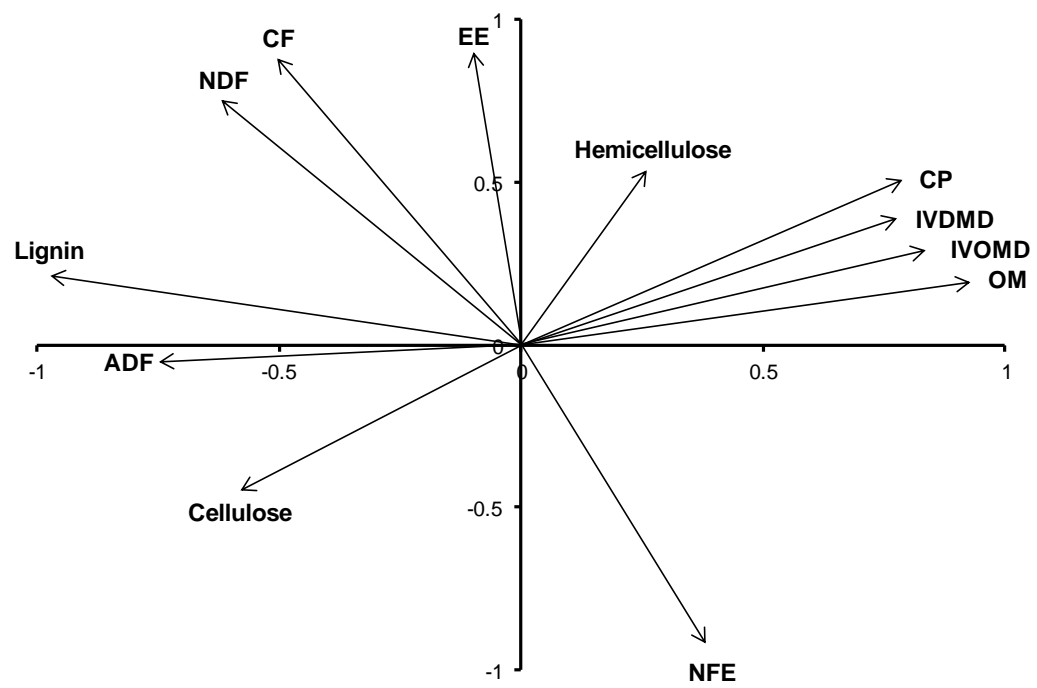

Figure 2. Loading plot of principal component 1 ( $\mathrm{PC} 1, \mathrm{x}$ axis, $49.4 \%$ from total variation) and principal component 2 (PC2, y axis, $31.2 \%$ from total variation), describing the relationship among parameters of chemical composition and in vitro digestibility. ADF, acid detergent fiber; CF, crude fiber; CP, crude protein; EE, ether extract; IVDMD, in vitro dry matter digestibility; IVOMD, in vitro organic matter digestibility; NDF, neutral detergent fiber; NFE, nitrogen free extract; OM, organic matter.

and IVOMD.

\section{In vivo evaluation}

Dry matter intake by steers fed the ration containing $\mathrm{CAm}$ or $\mathrm{CPh}$ was significantly $(\mathrm{p}<0.05$; Table 3 ) higher than that of the steers fed the control ration. However, $\mathrm{N}$ intake of the steers did not differ amongst the treatments. Fungal treatment of cocoa pod, i.e. $\mathrm{CPh}$ appeared to be superior as compared to other treatments in term of NDF and ADF intake. With regard to apparent digestibility, there were no differences in DM and OM digestibility amongst the treatment groups. However, $\mathrm{N}$ digestibility was significantly $(\mathrm{p}<0.05)$ higher for $\mathrm{CPh}$ compared to all other treatments $(p<0.05)$ with the exception of CAm. Higher $\mathrm{NDF}$ and ADF digestibilities of $\mathrm{CPh}$ over other treatments were also observed $(p<0.05)$.

The average daily gain of steers receiving $\mathrm{CAm}$ or $\mathrm{CPh}$ treatment was significantly higher than that of control $(p<0.01)$ with an increase of $105 \%$ and $92 \%$, respectively. These higher daily gains were concomitant with higher $\mathrm{N}$ retention and proportion of $\mathrm{N}$ retention to $\mathrm{N}$ intake in $\mathrm{CAm}$ and $\mathrm{CPh}$ treatments as compared to the control $(\mathrm{p}<0.05)$. Feeding either CMo or CRu did not affect average daily gain compared to the feeding of the control ration (Table 4).

A higher ruminal ammonia concentration was observed in $\mathrm{CAm}$ and $\mathrm{CPh}$ than that of control $(\mathrm{p}<0.01$; Table 5).

Table 3. Influence of various chemical and biological treatments of cocoa pod on intake and digestibility of steers $(n=5)$

\begin{tabular}{|c|c|c|c|c|c|c|}
\hline \multirow{2}{*}{ Component } & \multicolumn{5}{|c|}{ Treatment } & \multirow{2}{*}{ p-value } \\
\hline & $\mathrm{C}$ & CAm & CMo & $\mathrm{CRu}$ & $\mathrm{CPh}$ & \\
\hline \multicolumn{7}{|c|}{ Intake $\left(\mathrm{g} / \mathrm{kg} \mathrm{BW} \mathrm{B}^{0.75} / \mathrm{d}\right)$} \\
\hline $\mathrm{DM}$ & $104.0^{\mathrm{a}}$ & $116.2^{\mathrm{b}}$ & $109.8^{\mathrm{ab}}$ & $112.6^{\mathrm{ab}}$ & $117.1^{\mathrm{b}}$ & $<0.05$ \\
\hline $\mathrm{OM}$ & $52.6^{\mathrm{a}}$ & $91.2^{\mathrm{b}}$ & $85.6^{\mathrm{b}}$ & $90.9^{\mathrm{b}}$ & $92.6^{\mathrm{b}}$ & $<0.05$ \\
\hline $\mathrm{N}$ & 2.62 & 2.90 & 2.73 & 2.79 & 3.03 & ns \\
\hline $\mathrm{NDF}$ & $72.1^{\mathrm{ab}}$ & $67.2^{\mathrm{a}}$ & $62.8^{\mathrm{a}}$ & $72.0^{\mathrm{ab}}$ & $76.7^{\mathrm{b}}$ & $<0.05$ \\
\hline $\mathrm{ADF}$ & $53.8^{\mathrm{ab}}$ & $56.1^{\mathrm{b}}$ & $49.7^{\mathrm{a}}$ & $53.9^{\mathrm{ab}}$ & $57.2^{\mathrm{b}}$ & $<0.05$ \\
\hline \multicolumn{7}{|c|}{ Digestibility (\%) } \\
\hline $\mathrm{DM}$ & 49.6 & 50.1 & 48.3 & 51.0 & 55.0 & ns \\
\hline $\mathrm{OM}$ & 40.3 & 43.0 & 40.5 & 45.5 & 49.3 & ns \\
\hline $\mathrm{N}$ & $41.8^{\mathrm{a}}$ & $51.9^{\mathrm{ab}}$ & $42.8^{\mathrm{a}}$ & $44.3^{\mathrm{a}}$ & $55.2^{\mathrm{b}}$ & $<0.05$ \\
\hline $\mathrm{NDF}$ & $31.6^{\mathrm{ab}}$ & $30.6^{\mathrm{ab}}$ & $26.8^{\mathrm{a}}$ & $40.5^{\mathrm{bc}}$ & $45.5^{\mathrm{b}}$ & $<0.05$ \\
\hline $\mathrm{ADF}$ & $31.2^{\mathrm{b}}$ & $26.7^{\mathrm{ab}}$ & $18.8^{\mathrm{a}}$ & $28.2^{\mathrm{ab}}$ & $36.1^{\mathrm{c}}$ & $<0.05$ \\
\hline
\end{tabular}

BW, body weight; DM, dry matter; OM, organic matter; N, nitrogen; ns, non-significant; NDF, neutral detergent fiber; ADF, acid detergent fiber.

${ }^{1} \mathrm{C}$, cocoa pod without any treatment; CAm, ammoniated cocoa pod with $1.5 \%$ urea; CMo, fermented cocoa pod with $3 \%$ molasses; CRu, fermented cocoa pod with $3 \%$ rumen content; $\mathrm{CPh}$, fermented cocoa pod with $3 \%$ molasses and Phanerochaete chrysosporium inoculum.

Different superscripts within the same row are significantly different at $\mathrm{p}<0.05$. 
Table 4. Influence of various chemical and biological treatments of cocoa pod on body weight gain and nitrogen utilization of steers $(\mathrm{n}=$ 5)

\begin{tabular}{|c|c|c|c|c|c|c|}
\hline \multirow{2}{*}{ Component } & \multicolumn{5}{|c|}{ Treatment } & \multirow{2}{*}{$\mathrm{p}$-value } \\
\hline & $\mathrm{C}$ & CAm & CMo & $\mathrm{CRu}$ & $\mathrm{CPh}$ & \\
\hline \multicolumn{7}{|l|}{ Body weight } \\
\hline ADG (kg/d) & $0.76^{\mathrm{a}}$ & $1.56^{\mathrm{b}}$ & $0.94^{\mathrm{a}}$ & $0.75^{\mathrm{a}}$ & $1.46^{\mathrm{b}}$ & $<0.01$ \\
\hline \multicolumn{7}{|l|}{$\mathrm{N}$ utilization } \\
\hline $\mathrm{N}$ retention $\left(\mathrm{g} / \mathrm{kg} \mathrm{BW} \mathrm{W}^{0.75} / \mathrm{d}\right)$ & $1.06^{\mathrm{a}}$ & $1.45^{\mathrm{b}}$ & $1.12^{\mathrm{a}}$ & $1.16^{\mathrm{a}}$ & $1.60^{\mathrm{b}}$ & $<0.01$ \\
\hline $\mathrm{N}$ retention/ $\mathrm{N}$ intake $(\%)$ & $40.6^{\mathrm{a}}$ & $50.1^{\mathrm{b}}$ & $41.4^{\mathrm{a}}$ & $43.0^{\mathrm{a}}$ & $53.0^{\mathrm{b}}$ & $<0.05$ \\
\hline
\end{tabular}

ADG, average daily gain; $\mathrm{BW}$, body weight; $\mathrm{N}$, nitrogen.

${ }^{1} \mathrm{C}$, cocoa pod without any treatment; CAm, ammoniated cocoa pod with $1.5 \%$ urea; CMo, fermented cocoa pod with $3 \%$ molasses; CRu, fermented cocoa pod with $3 \%$ rumen content; $\mathrm{CPh}$, fermented cocoa pod with $3 \%$ molasses and Phanerochaete chrysosporium inoculum.

Different superscripts within the same row are significantly different at $\mathrm{p}<0.05$.

Similarly, both treatments produced higher total VFA concentrations compared to control $(\mathrm{p}<0.01)$, primarily as a result of an increase in both acetate and propionate. In the case of rumen microbial protein yield and allantoin urine, only $\mathrm{CPh}$ had the respective values higher than those of control (both at $\mathrm{p}<0.01$ ) with an increase of $106 \%$ and $54 \%$, respectively.

\section{DISCUSSION}

Crude protein content of untreated cocoa pod obtained in this study was within the common range reported by other authors (Owusu-Domfeh, 1972; Sutikno, 1997; Zain, 2009). The increased $\mathrm{CP}$ content of the pod in $\mathrm{CPh}$ treatment compared to that of control could be attributed to mycelia growth of the fungi which is high in protein (Ghorai et al., 2009). It is also possible that protein increase (per unit dry matter) is due to a dry matter loss as a consequence of fungal growth (Zadrazil et al., 1996; Misra et al., 2007); dry matter loss of cocoa pod due to $P$. chrysosporium treatment in this study was $9.4 \%$, while the loss of other treatments was much lower (ranged between
$2.6 \%$ to $6.3 \%$ ). Although treatment with white rot fungi may increase digestibility of a feed quite significantly (Karunanandaa et al., 1995), a problem with such treatment is a loss of yield or biomass since fungi require and utilize part of feed nutrients for their metabolism and activity. This occurs with a higher magnitude typically when the substrate is rich in easily fermentable components such as sugar, starch and protein, but less biomass loss when the substrate is rich in fibrous materials. Therefore one has to consider the benefit as well as the limitation of using fungal treatment prior to applying the technology in practice.

Fungi $P$. chrysosporium has the capability to produce lignin-degrading enzymes, i.e. lignin peroxidases and manganese peroxidases (Gold and Alic, 1993; Singh and Chen, 2008) which enable the fungi to degrade the aromatic structure of lignin and release cellulose or hemicellulose attached to lignin to be further used by rumen microbes and their host animals. Apart from producing lignin-degrading enzymes, $P$. chrysosporium also produces cellulase and hemicellulase (xylanase) enzymes (Dashtban et al., 2009). It has been widely known that high ADF and/or lignin in a feed are related to its low digestibility, and vice versa

Table 5. Influence of various chemical and biological treatments of cocoa pod on rumen fermentation parameters of steers $(n=5)$

\begin{tabular}{|c|c|c|c|c|c|c|}
\hline \multirow{2}{*}{ Component } & \multicolumn{5}{|c|}{ Treatment $^{1}$} & \multirow{2}{*}{ p-value } \\
\hline & $\mathrm{C}$ & CAm & CMo & $\mathrm{CRu}$ & $\mathrm{CPh}$ & \\
\hline$\overline{\mathrm{pH}}$ & 6.06 & 6.26 & 6.21 & 6.15 & 6.38 & $\mathrm{~ns}$ \\
\hline $\mathrm{NH}_{3}(\mathrm{mM})$ & $4.69^{\mathrm{a}}$ & $6.30^{\mathrm{b}}$ & $4.18^{\mathrm{a}}$ & $4.84^{\mathrm{a}}$ & $5.90^{\mathrm{b}}$ & $<0.01$ \\
\hline \multicolumn{7}{|l|}{ VFA (mM) } \\
\hline Total & $94.7^{\mathrm{a}}$ & $109.7^{\mathrm{b}}$ & $103.1^{\mathrm{ab}}$ & $99.3^{\mathrm{ab}}$ & $111.0^{\mathrm{b}}$ & $<0.01$ \\
\hline $\mathrm{C}_{2}$ & $63.3^{\mathrm{a}}$ & $73.9^{\mathrm{b}}$ & $69.7^{\mathrm{b}}$ & $69.5^{\mathrm{b}}$ & $72.5^{\mathrm{b}}$ & $<0.05$ \\
\hline $\mathrm{C}_{3}$ & $22.5^{\mathrm{a}}$ & $26.6^{\mathrm{b}}$ & $23.0^{\mathrm{a}}$ & $19.7^{\mathrm{a}}$ & $29.2^{\mathrm{b}}$ & $<0.01$ \\
\hline $\mathrm{C}_{4}$ & 5.10 & 5.25 & 5.74 & 6.09 & 5.05 & ns \\
\hline iso $_{4}$ & 2.79 & 3.41 & 3.32 & 2.98 & 3.49 & $\mathrm{~ns}$ \\
\hline $\mathrm{C}_{5}$ & 1.02 & 0.58 & 1.35 & 1.05 & 0.73 & ns \\
\hline Microbial protein $(\mathrm{g} / \mathrm{d})$ & $253.2^{\mathrm{a}}$ & $298.9^{\mathrm{a}}$ & $317.5^{\mathrm{a}}$ & $330.5^{\mathrm{a}}$ & $520.4^{\mathrm{b}}$ & $<0.01$ \\
\hline Allantoin urine $(\mathrm{g} / \mathrm{d})$ & $3.32^{\mathrm{ab}}$ & $3.98^{\mathrm{b}}$ & $3.69^{\mathrm{ab}}$ & $2.85^{\mathrm{a}}$ & $5.10^{\mathrm{c}}$ & $<0.01$ \\
\hline
\end{tabular}

ns, non-significant; VFA, volatile fatty acid; $C_{2}$, acetate; $C_{3}$, propionate; $C_{4}$, butyrate; $C_{5}$, valerate.

${ }^{1} \mathrm{C}$, cocoa pod without any treatment; CAm, ammoniated cocoa pod with $1.5 \%$ urea; CMo, fermented cocoa pod with $3 \%$ molasses; CRu, fermented cocoa pod with $3 \%$ rumen content; $\mathrm{CPh}$, fermented cocoa pod with $3 \%$ molasses and Phanerochaete chrysosporium inoculum.

Different superscripts within the same row are significantly different at $\mathrm{p}<0.05$. 
(Vadiveloo et al., 2009; Sarnklong et al., 2010). Structural modification of cell wall components due to the respective urea or fungal treatment appears to facilitate fiberdegrading microbes in the rumen to degrade fibrous components more intensively and therefore increasing the digestibility of feed (Wanapat, 2000). Altogether, such conditions causes massive fiber degradation as confirmed by a decrease in NDF and ADF contents of cocoa pod as well as an increase in IVDMD and IVOMD.

Urea treatment appeared to be effective in improving nutritive value of cocoa pod like that of $P$. chrysosporium. Lower ADF content of cocoa pod due to urea treatment observed in this study was in agreement with Zain (2009); the author observed that treating cocoa pod with $6 \%$ urea and kept for $21 \mathrm{~d}$ decreased ADF by $8.2 \%$. Urea is a source of ammonia after being hydrolyzed to produce stepwise ammonium carbamate and ammonium carbonate. Such treatment reduces physical strength of especially fibrous feed, disrupts the silicified cuticular barrier and cleavages of some lignin-carbohydrate bonds (Schiere and Nell, 1993; Van Soest, 2006). As a consequence of this, the digestibility of urea-treated cocoa pod increased as shown by higher IVDMD and IVOMD values compared to the control. It is further confirmed by the PCA loading plot that there was a positive correlation between digestibility and $\mathrm{CP}$, and a negative correlation between digestibility and fiber fractions. Such relationships are in agreement with results obtained from other studies (Barahona et al., 2003; Karabulut et al., 2007), confirming the already established relationships among the respective parameters.

The effectiveness of $P$. chrysosporium or urea treatment in modifying chemical composition and digestibility of cocoa pod towards a favourable direction is reflected in the performance of steers in vivo. Higher dry matter intake of steers consuming $\mathrm{CAm}$ or $\mathrm{CPh}$ as compared to that of control is apparently due to faster fermentation rate as a result of higher fiber degradation in the treated cocoa pod rations, allowing the steers to eat more. Interestingly, there was lack of treatment effects on DM and OM digestibility of steers. Conway et al. (2012) reported similar response in which a higher intake was not accompanied with a change in digestibility. It seems that higher intake increases rate of passage and in turn makes no difference in the digestibility observed. Nutrient supply for the steers consuming CAm or $\mathrm{CPh}$ rations is higher due to the higher dry matter intake, which is then beneficial for the improvement of their productivity as shown by higher average daily gain and higher $\mathrm{N}$ retention. A greater nutrient supply also provides more substrate for rumen microbes to grow and to yield more microbial protein from their biomass (Clark et al., 1992; Bach et al., 2005), which is also observed in this study. When the microbes are abundant and active, an elevated VFA concentration is expected as the end product of microbial fermentation in the rumen (Kamra, 2005). Increasing rumen ammonia concentrations of steers fed with $\mathrm{CAm}$ or $\mathrm{CPh}$ were probably due to the tendency of higher $\mathrm{N}$ intakes in the corresponding treatments. Further, treatment of cocoa pod with either ammoniation or Phanerochaete chrysosporium fungi apparently increases the proportion of rumen degradable protein over the undegradable protein, thus contributing to the increase of ammonia concentration.

Based on the results obtained, it is concluded that the limitation of nutritional quality of cocoa pod can be overcome, at least partially, through treatments. Treatment with urea (ammoniation technique) or Phanerochaete chrysosporium in particular shows a comparative advantage over other treatments. Apart from modifying structural carbohydrate of cocoa pod, urea treatment may provide an additional source of nitrogen which can be utilized by rumen microbes for their microbial protein synthesis and subsequent utilization of the protein by the host animals. Animals receiving diets containing the urea or fungal treated cocoa pods responded positively over the control group in terms of average daily gain, nitrogen utilization and a number of rumen fermentation parameters. This is in accordance with a compositional change occurs in cocoa pod after being treated. Treatment by using white rot fungi species like Phanerochaete chrysosporium nevertheless needs a special attention since, apart from its effectiveness in degrading lignin aromatic structure as well as cellulose or hemicellulose attached to the substance, it consumes part of the nutrients in feed and causes some biomass losses.

\section{ACKNOWLEDGMENTS}

The authors are grateful to all staff in the Laboratory of Feed Science and Technology, Bogor Agricultural University, for their excellent technical assistance throughout the experimental period.

\section{REFERENCES}

Alemawor, F., V. P. Dzogbefia, E. O. K. Oddoye, and J. H. Oldham. 2009. Effect of Pleurotus ostreatus fermentation on cocoa pod husk composition: Influence of fermentation period and $\mathrm{Mn}^{2+}$ supplementation on the fermentation process. Afr. J. Biotechnol. 8:1950-1958.

AOAC. 1995. Official Methods of Analysis. 16th edn. Association of Official Analytical Chemists, Arlington, VA, USA.

Aregheore, E. M. 2002. Chemical evaluation and digestibility of cocoa (Theobroma cacao) byproducts fed to goats. Trop. Anim. Health Prod. 34:339-348.

Bach, A., S. Calsamiglia, and M. D. Stern. 2005. Nitrogen metabolism in the rumen. J. Dairy Sci. 88(Suppl. 1):E9-21.

Barahona, R., C. E. Lascano, N. Narvaez, E. Owen, P. Morris, and M. K. Theodorou. 2003. In vitro degradability of mature and 
immature leaves of tropical forage legumes differing in condensed tannin and non-starch polysaccharide content and composition. J. Sci. Food Agric. 83:1256-1266.

Bucholtz, H. F. and W. G. Bergen. 1973. Microbial phospholipid synthesis as a marker for microbial protein synthesis in the rumen. Appl. Microbiol. 25:504-513.

Clark, J. H., T. H. Klusmeyer, and M. R. Cameron. 1992. Microbial protein synthesis and flows of nitrogen fractions to the duodenum of dairy cows. J. Dairy Sci. 75:2304-2323.

Conway, E. J. and A. Byrne. 1933. An absorption apparatus for the micro-determination of certain volatile substances. I. The micro-determination of ammonia. Biochem. J. 27:419-429.

Conway, L. K., D. M. Hallford, and S. A. Soto-Navarro. 2012. Effects of wet corn gluten feed and yellow grease on digestive function of cattle fed steam-flaked corn-based finishing diets. Anim. Feed Sci. Technol. 178:20-26.

Cottyn, B. G. and C. V. Boucque. 1968. Rapid method for the gaschromatographic determination of volatile fatty acids in rumen fluid. J. Agric. Food Chem. 16:105-107.

Dashtban, M., H. Schraft, and W. Qin. 2009. Fungal bioconversion of lignocellulosic residues: Opportunities and perspectives. Int. J. Biol. Sci. 5:578-595.

Devendra, C. 1977. The utilization of cocoa pod husk by sheep. Malaysian Agric. J. 51:179-185.

FAOSTAT. 2013. Food and Agriculture Organization of the United Nations. http://faostat3.fao.org/faostat-gateway/go/to/home/E. Accessed March 3, 2014.

Ghorai, S., S. P. Banik, D. Verma, S. Chowdhury, S. Mukherjee, and S. Khowala. 2009. Fungal biotechnology in food and feed processing. Food Res. Int. 42:577-587.

Gold, M. H. and M. Alic. 1993. Molecular biology of the lignindegrading basidiomycete Phanerochaete chrysosporium. Microbiol. Mol. Biol. Rev. 57:605-622.

Jayanegara, A., E. Wina, C. R. Soliva, S. Marquardt, M. Kreuzer, and F. Leiber. 2011. Dependence of forage quality and methanogenic potential of tropical plants on their phenolic fractions as determined by principal component analysis. Anim. Feed Sci. Technol. 163:231-243.

Kamra, D. N. 2005. Rumen microbial ecosystem. Curr. Sci. 89:124-135.

Karabulut, A., O. Canbolat, H. Kalkan, F. Gurbuzol, E. Sucu, and I. Filya. 2007. Comparison of in vitro gas production, metabolizable energy, organic matter digestibility and microbial protein production of some legume hays. Asian Australas. J. Anim. Sci. 20:517-522.

Karunanandaa, K., G. A. Varga, D. E. Akin, L. L. Rigsby, and D. J. Royse. 1995. Botanical fractions of rice straw colonized by white-rot fungi: changes in chemical composition and structure. Anim. Feed Sci. Technol. 55:179-199.
Kim, Y. I., Y. H. Lee, K. H. Kim, Y. K. Oh, Y. H. Moon, and W. S. Kwak. 2012. Effects of supplementing microbially-fermented spent mushroom substrates on growth performance and carcass characteristics of Hanwoo steers (a field study). Asian Australas. J. Anim. Sci. 25:1575-1581.

Misra, A. K., A. S. Mishra, M. K. Tripathi, R. Prasad, S. Vaithiyanathan, and R. C. Jakhmola. 2007. Optimization of solid state fermentation of mustard (Brassica campestris) straw for production of animal feed by white rot fungi (Ganoderma lucidum). Asian Australas. J. Anim. Sci. 20:208213.

Owusu-Domfeh, K. 1972. The future of cocoa and its by-products in the feeding of livestock. Ghana J. Agric. Sci. 5:57-64.

Sarnklong, C., J. W. Coneja, W. Pellikaan, and W. H. Hendriks. 2010. Utilization of rice straw and different treatments to improve its feed value for ruminants: A review. Asian Australas. J. Anim. Sci. 23:680-692.

Schiere, J. B. and A. J. Nell. 1993. Feeding of urea treated straw in the tropics. I. A review of its technical principles and economics. Anim. Feed Sci. Technol. 43:135-147.

Singh, D. and S. Chen. 2008. The white-rot fungus Phanerochaete chrysosporium: Conditions for the production of lignindegrading enzymes. Appl. Microbiol. Biotechnol. 81:399-417.

Smith, O. B. and A. A. Adegbola. 1982. The feeding value of cocoa-pod for cattle. Trop. Anim. Prod. 7:290-295.

Sutikno, A. I. 1997. Cocoa pod for feeding of ruminant livestock. Wartazoa 6:38-43.

Tilley, J. M. A. and R. A. Terry. 1963. A two-stage technique for the in vitro digestion of forage crops. Grass Forage Sci. 18:104-111.

Vadiveloo, J., B. Nurfariza, and J. G. Fadel. 2009. Nutritional improvement of rice husks. Anim. Feed Sci. Technol. 151:299305.

Van Soest, P. J., J. B. Robertson, and B. A. Lewis. 1991. Methods for dietary fiber, neutral detergent fiber, and nonstarch polysaccharides in relation to animal nutrition. J. Dairy Sci. 74:3583-3597.

Van Soest, P. J. 2006. Rice straw, the role of silica and treatments to improve quality. Anim. Feed Sci. Technol. 130:137-171.

Wanapat, M. 2000. Rumen manipulation to increase the efficient use of local feed resources and productivity of ruminants in the tropics. Asian Australas. J. Anim. Sci. 13(Suppl. B):59-67.

Zadrazil, F., D. N. Kamra, O. S. Isikhuemhen, F. Schuchardt, and G. Flachowsky. 1996. Bioconversion of lignocellulose into ruminant feed with white rot fungi - Review of work done at the FAL, Braunschweig. J. Appl. Anim. Res. 10:105-124.

Zain, M. 2009. Substitution of native grass with ammoniated cocoa pod in sheep diet. Media Peternakan 32:47-52.

Zinn, R. A. and F. N. Owens. 1986. A rapid procedure for purine measurement and its use for estimating net ruminal protein synthesis. Can. J. Anim. Sci. 66:157-166. 